\title{
リンゴ實腐病と授粉との關係
}

皇 善 鄰

(北海道需國大學曟學部)

本病は所謂モニリア病(Sclerotinia Mali TAKaHashr, Sclerotinio Malicola M. MrURA）の一種でリンゴの花より椎棵に至る間に發生し大整を與ふるものであ

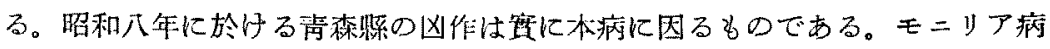

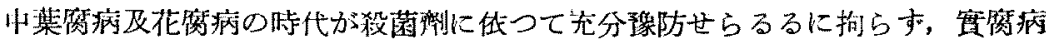

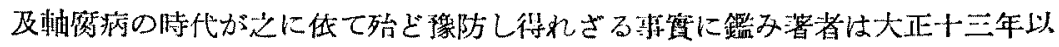

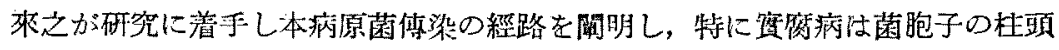
传入 (stigma-infecton) k起因する事の算驗的證明を得爾來杜頭侵入後の菌行

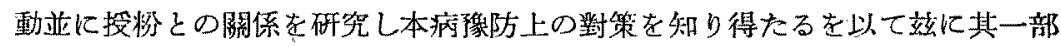
を報告せんとするものである。

本邦研究者の間では從來杜䫓传入に對する意見が一致しなかつたが海外では

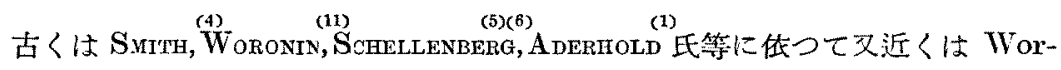
mald 氏に依つて認められて居る。然し杜頭侵入後の菌行動に就きての報告は 越椅に於ける WoRONIN 氏及榅桲に於ける SUHELLENBERG 氏の報告があるに

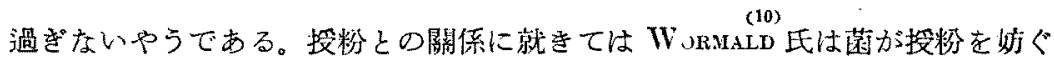
る事を逃へ，SCHELLENBERG 氏は Mespilus に於て菌核の形成は挼精後の菌佼 入に於てのみ認められると逃ぐたるものがあるに過ぎない。

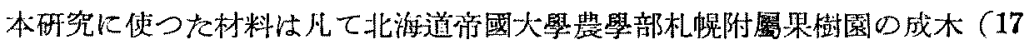
年生)で「リンゴ」の外橾桃, 和李, 洋梨, 和梨, 想桲及「メドラ」をも用ひ「リンゴ」

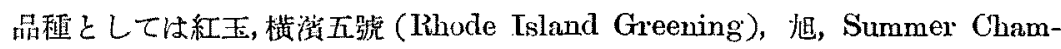
pion, 倭錦, Cox's Orange 老倛し, 1929, 1930 及 1931 の三年間に篮驗した。 花粉管及菌の行動を追跡するための研究材料忏野外ばかりでなく溫室(約 $\left.25^{\circ} \mathrm{C}\right)$ 及恆溫器 $\left(20^{\circ} \mathrm{C}\right)$ 队の町花を利用して接種及授粉を行ひ定時間に探收固定した。 接種には大型分生胞子を煳，授粉は闹種及異種の网者を行つた。间定液とし

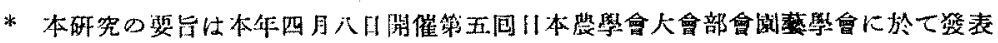


て FlEMMNG E液及 CanNoY 氏㴕を染色には主として $0.1 \%$ cotton blue 乳酸

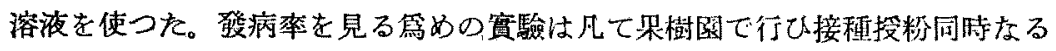

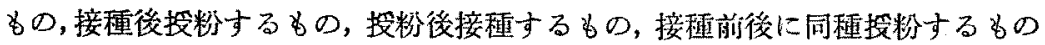
及異種授粉するものの五種の菑驗を行つた。

先づ解剖學的呼究の結果を概括するこ次の如くである。大型分生胞子 (11. $75 \times 9.40 \%-7.05 \times 4.70 \mu)$ は杜頭に於て 6 洔間以队に發苏して通導組織の紡綞細 胞 (prosenchymatous cells) の閒に入り,殆ど直線に俳長し，䉼次直徑索增加し

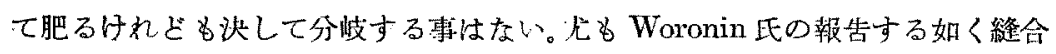
(amastomose) はするやうである。而して菌體又法大なる空胞を生するから道 路には特有なる畨を呈する。著者は便宜上之に岿路(mycelial passage)なる名

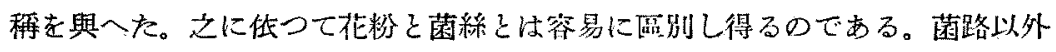

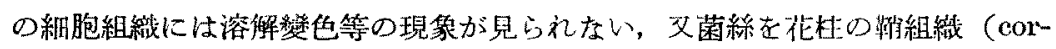

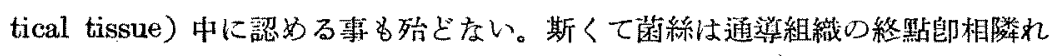

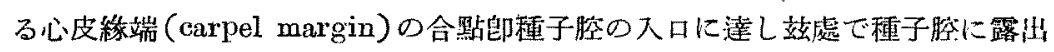

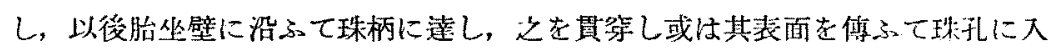

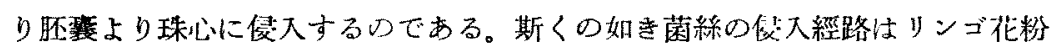
管の經路に全然一致するものである。WoKONIN 氏はVaceinium に於て菌絲は 花粉管と其に通導組織を過ぎ種子腔に達するも直に附近組織を㒛害する事走報 告した。乙に反し SCHELLENBERG 氏は相桲に於て菌綵は花粉管を同一D經路を 辿り，先つ種子原體を位す事を報告し，幸荤なる切片にては芼綵の珠扎通過を

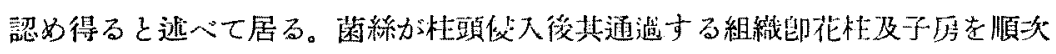

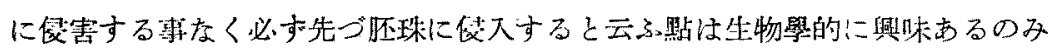

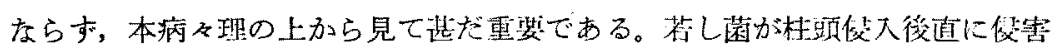

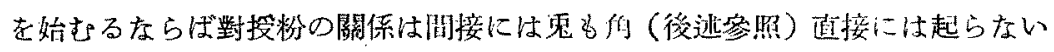

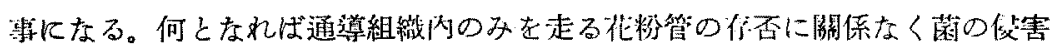
は行はれるであらうからである。

唒茲に注意すべき事は本邦に於ては想模，洋梨及和梨に於て此實腐病が知ら れて居ない。然るに著都は是等果樹の杜影に「リンダ」より得たる「モニリア」胞 子を接種し菌が「リンゴ」の場合と闹樣に原珠に佼入するのを認か而かる和梨に 


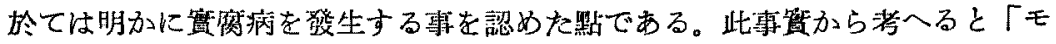
ニリア菌の杜頭信入は其普邀性であつて, 菌の柱頭侵入は此種病原菌が新寄主 を得る所の撮初の手段になるのではないかと思はれるのである。壮リンゴ」に 於ては勿論他の仁果類に於ても桂顽俊入が花朵脫離 (abscission)の一原因とし て裁培上重要悓すべきであると思ふのである。

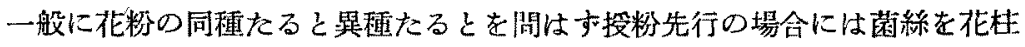
其部迄の間に認め得るも，光程子柾及肧珠内に認める事が少い。之に反し花

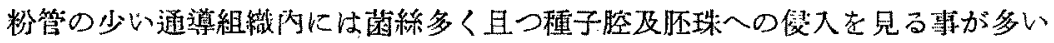
のである。文著者の研究結果から見ると同種の花粉管は花杜泚部迄はよく到達 するが種子腔に侵入するものは極めて少く且一般に進行が鈍い，之に反し黑種 花粉管流に多數を花柱內に認められるし且種子腔に入り結局辰素に達するも のも多いのである。通導組織內に於て啨極的に花粉管と菌絲とが相互に妨害せ られたと認むべき現象に接し得なんたが，少くとも花粉營先行のものに於て菌 に传入された胀珠の少い點から見て此場合には菌絲の侵入が花粉管に依つて阻 止せられたと認むべきである。之に反し菌絲先行すれば花粉管の進行の阻此せ らるべきは花粉管其ものの生理から見て明かである。

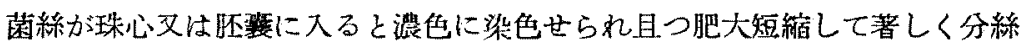

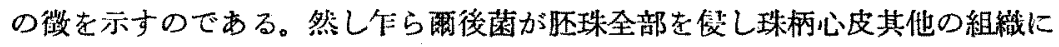
㕠延して惯腐病として病徽を呈する篇めには一部の脴珠が授精を完了して各組 織の發達を來すか或は少くとも單篇結果的の發育を必要とする。故に压珠の一 部が授精し，他の一部が菌侵害を見た時或は投情せざるも單第結果的發育の比

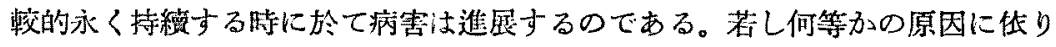

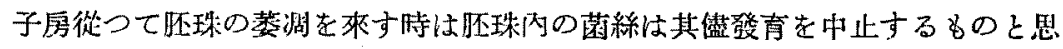

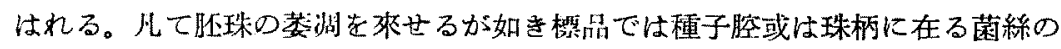
桜色选だ不良で，獨り顺珠队の菌絲のみ榾濃原に染色せられる。

花粉管進行は溫度に撮も卙感に反热する。例入ば授粉先行の場合でも低溫な る時は肧珠に到達するに120一216㭙間を要するに反し高溫なる時は72時間で到

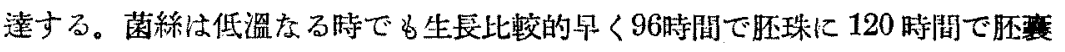
耴大り。高溫の㭙は66時間內外で珠柄に90㭙間で肧垔に侵入する。著者の得た 


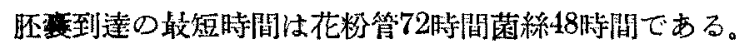

然らば授粉と發病との關係は何うなるか，慈には1931に得た一例を示す事に する。第一裴は之を示するのである。

第一表 授粉と接種が相前後したる場合の發病率(1931)

接種品種紅玉，授粉品種隼錦; 揟粉接種 $9 / V I-15 / V I$ 调查 $23 / \mathrm{VI}$

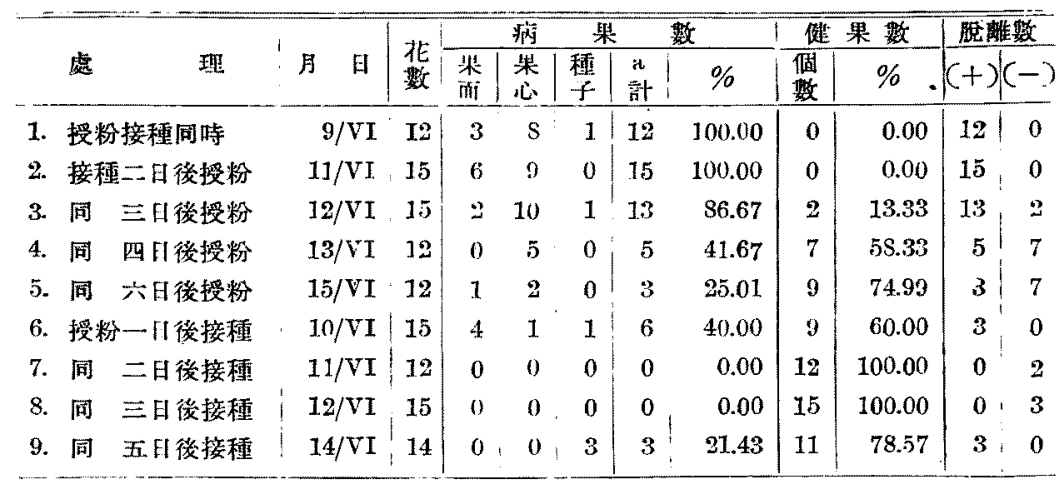

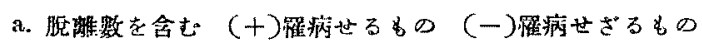

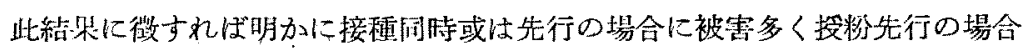
に尠きを見るであらう，殊に授粉後接種の後るるに從つて著しく發病率を減す る事が知られる。授粉五日後に接種したものに $21.43 \%$ 發病を示して居るが，

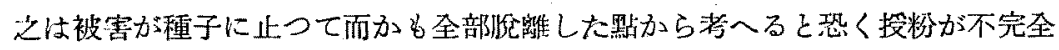

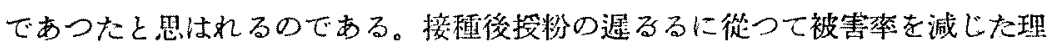

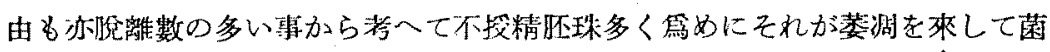
係の發達を却て阻止した結果に依るものと思はれる。

同種授粉と異程摄粉とを比較すると一般に前者の場、合が高率の被害を與人

る，例へば1929年に得た一結果を示すと第二裴の如くである。

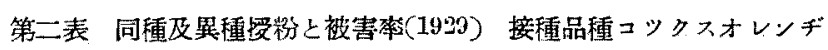
授粉品種傮錦，除萂 $8 / V I$ 揬種授粉 $9 / \mathrm{VI}$ 調查 $19 / \mathrm{VI}$

\begin{tabular}{|c|c|c|c|c|c|c|c|c|c|c|}
\hline \multirow[b]{2}{*}{ 處 } & \multirow[b]{2}{*}{ 理 } & \multirow[b]{2}{*}{ 北 数 } & \multicolumn{3}{|c|}{ 为高 } & 數 & 果 & \multirow{2}{*}{ 健果數 } & 脘 & 制 \\
\hline & & & 樂 & 解 & 䊏 心 & 計 & $\%$ & & $(+)$ & $(-)$ \\
\hline 同香 & 受粉 & 14 & & 0 & 12 & 12 & 85.70 & 0 & 2 & 0 \\
\hline 異秉 & 粉 & 18 & & 6 & 4 & 10 & 55.60 & 4 & 4 & 0 \\
\hline
\end{tabular}

然し異種挼粉と踓も接種が问㭙或は先行であり，殊に氣溫の低い㭙は被害率 
はやはり高いのである。

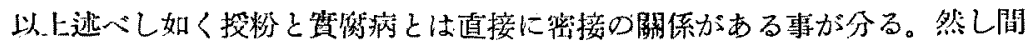

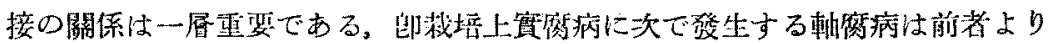

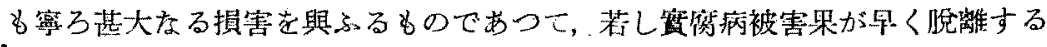

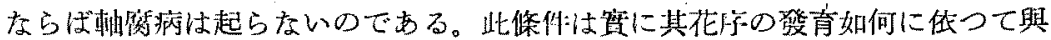
へられるのである。即一花此に一個の健全にして發育旺盛なる稚果位声る㭙

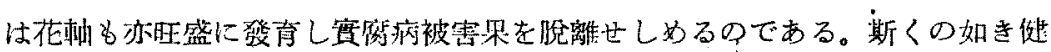

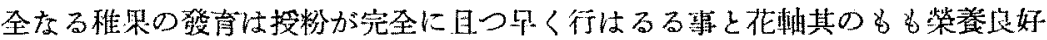

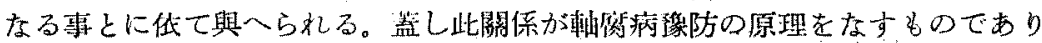
吾人が前定肥塔を重装なりにする所以に外ならない。然して挼粉授精の安全を

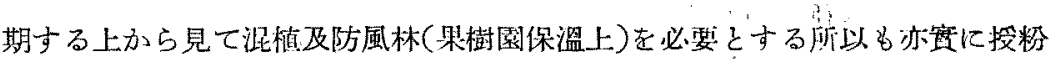
と本病菌との闑接的關係に低するのである。

\section{引用文 䖒}

(1) 1905. Aoerhoud, R. and Rulluan, W. : Zur Kenntnis der Obstbaumsclerotinien. Arbeit. a: d. Biol. Abt. f. Land-und Forstw, an Kaisl, Gesdamt. IV : $427-41$.

(2) 1906. HLnzaWd, J. : Fulatabi Kaju no Mouilia byo ni Tsuki te 1906. Hanzawa, J.: Solerotinia Diseases of $R$ ssaceous Plants in Jipan. Trans. Sapporo Nat. Hist. Səc. I. Pt. I : 97-10j.

(3) 1915. Mrura, M. : Heika Byogai ni kansuru Ghôsa. Awomori ken Noji Shiken Jo Seiseki. No. XV : 1-141.

(4) 1889. Suith, E. F. : Peach RJt and Peach Blight. The Journ. Mycol. V : $123-34$.

(5) 1899. S yellembers, H. C. : Ueber die Sulerotienkrankheit der Quitte. Ber. a. d. Bot. Ges. XVII : 205-15.

(6) 1907. ................... : Ceber Selerotinit Mespili u. S. Arine. Centbl. f. Bak. II Abt. XVII : 188-202.

(7) 1924. S ImA , Y. : Rivgo Mikusarebyo no Yobohkujo ni tsuki te Engei XVII $9: 1-26$.

(s) 1927. .......... : Ringo Mikusarebyogenkin no Chuto Shinnyu ni tsuki te. Nogyo oyobi Engei, II : 233-3S.

(9) 1915. 'TakaHAsH, Y. : Heika Hanakusarebyo oyobi Mikusarebyo ni tsuki to. Shokubutsugaku Zissi, $343: 217-23$.

(10) 1917. Worarald, H. : A Bloosnm-Wilt and Canker of Apple Trees. Ann. Appl. Biol. III : S59-203, 1916-1917.

(11) 1888. Woronts, M. : Ueber die Sclerotienkrunkheit der Vactinien-Beeren. Mem. de LiAcat. Imper. des Sci. de St.-Petersb. VII Serie, Tom. XXXVI N6: $1-49$. 